\title{
Flexible pavement rehabilitation with continuously reinforced concrete slab with HFRP bars - mechanistic analysis
}

\author{
Magdalena Złotowska ${ }^{1}$, Roman Nagórski ${ }^{2}$, Piotr Radziszewski ${ }^{3, *}$, Michał Sarnowski ${ }^{4}$, and Paweł Tutka ${ }^{5}$ \\ ${ }^{1}$ MSc., Eng., Warsaw University of Technology, Faculty of Civil Engineering, L. Kaczyńskiego 16, 00-637 Warsaw, Poland \\ ${ }^{2}$ Prof., PhD., Eng., Warsaw University of Technology, Faculty of Civil Engineering, L. Kaczyńskiego 16, \\ 00-637 Warsaw, Poland \\ ${ }^{3}$ Prof., PhD., Eng., Warsaw University of Technology, Faculty of Civil Engineering, L. Kaczyńskiego 16, 00-637 Warsaw, Poland \\ ${ }^{4} \mathrm{PhD}$., Eng., Warsaw University of Technology, Faculty of Civil Engineering, L. Kaczyńskiego 16, 00-637 Warsaw, Poland \\ ${ }^{5} \mathrm{MSc}$, Eng., Warsaw University of Technology, Faculty of Civil Engineering, L. Kaczyńskiego 16, \\ 00-637 Warsaw, Poland
}

\begin{abstract}
Asphalt road pavements are subject to damage under the influence of loads from the traffic of vehicles and of the environmental factors. One of the ways to strengthen damaged flexible pavements is to apply a cement concrete overlay with continuous reinforcement. The purpose of this paper is to analyze the road structure with concrete overlay with continuous reinforcement HFRP composite bars, which is laid on the existing cracked asphalt layers of a typical flexible road of KR3 traffic category. In HFRP bars some of the basalt fibers have been replaced with carbon fibers with the addition of resin binders. This do the possibility of making concrete slabs with increased resistance for environmental aggression, with good mechanical properties, which is especially important in the case of road constructions. An analysis of fatigue life of the strengthened asphalt pavement with a concrete slab with continuous reinforcement of HFRP bars was carried out, implementing the mechanistic model of the pavement structure. The stress analysis in the structure under the action of static loading was determined by the Finite Element Method using the Abaqus/Standard program. The maximum value of stress caused by temperature gradient in the concrete slab was calculated from the Westergaard's formula for infinite slab. It has been shown that strengthening the analyzed road pavement with a continuous reinforcement is a technology that ensures an increase in fatigue life and reinforcement with HFRP bars further increases durability due to the negative impact of environmental factors.
\end{abstract}

\section{Introduction}

Continuously increasing heavy traffic causes, that even correctly designed road pavement structures often deteriorate before reaching the originally designed service life. Asphalt pavements, most commonly used in Poland and worldwide for road construction, under the influence of traffic loads and the environmental factors undergo damage like rutting, low temperature and fatigue cracking and so on $[1,2]$. One of the possible ways to strengthen damaged asphalt pavements could be the overlay in the form of a relatively thin, rigid concrete slab with continuous steel reinforcement. The first experimental section of concrete pavement with continuous steel reinforcement was made in Poland in 2005 [3]. Currently, research is being carried out at the Warsaw University of Technology on the use of new generation HFRP (Hybrid Fiber Reinforced Polymer) composite bars for concrete slab reinforcement, in which some of the basalt fibers have been replaced with carbon fibers with the addition of resin binders $[4,5]$. This do the possibility of making concrete slabs with increased resistance for environmental aggression, with good mechanical properties $[6,7,8,9]$. As a result, the durability of the structure is improved, which is especially useful for road constructions.

The purpose of this paper is to analyze the road structure with concrete overlay with continuous reinforcement HFRP composite bars, which is laid on the damaged asphalt layers of a typical flexible road of KR3 traffic category. Such structure [10] is compared with the traditional slab with steel reinforcement. Analyzed pavement structure is shown in Fig. 1.

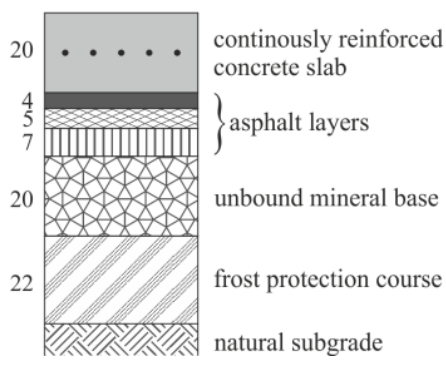

Fig. 1. Continuously reinforced whitetopping pavement structure

Corresponding author: p.radziszewski@il.pw.edu.pl 


\section{Assumptions and data}

\subsection{Computational model}

Due to the use of continuous reinforcement in the concrete overlay as a mechanistic model of the construction, a multi-layered elastic half space loaded axi-symmetrically was assumed. Partial joining of the concrete slab with the existing pavement construction was considered as an intermediate state between the full bonding of the concrete cement layer with the existing asphalt layers and the free slip between them.

The level of degradation of the existing flexible pavement structure was assumed in two variants:

a) weakened structure - module of stiffness of the asphalt layers set $E=5000 \mathrm{MPa}$

b) damaged structure - module of stiffness of the asphalt layers set $E=400 \mathrm{MPa}$

Geometric and material characteristics of the modeled pavement structure are given in Table 1.

Two types of load have been considered: - vertical load of the wheel of the $100 \mathrm{kN}$ standard axle. A load with a resultant $50 \mathrm{kN}$ (single-wheel load) uniformly distributed on a circular area with an intensity of $720 \mathrm{kPa}$ was assumed. (radius of the load area was equal to $0.1487 \mathrm{~m}$ )

- temperature gradient along the height of the concrete slab. The temperature difference was assumed equal to $8^{\circ} \mathrm{C}$ [11] (material data is presented in Table 2).

Table 1. Pavement structure geometric and material parameters used to calculate stress state due to the wheel load with the values of elasticity modulus of asphalt layers in two variants.

\begin{tabular}{|c|c|c|c|}
\hline Course & $\begin{array}{c}\text { Thickness } \\
\boldsymbol{h}[\mathbf{m m}]\end{array}$ & $\begin{array}{c}\text { Elasticity } \\
\text { module } \\
\boldsymbol{E}[\mathbf{M p a}]\end{array}$ & $\begin{array}{c}\text { Poisson's } \\
\text { ratio } \\
\boldsymbol{v}[-]\end{array}$ \\
\hline $\begin{array}{c}\text { Concrete } \\
\text { slab C35/45 }\end{array}$ & 20 & 35000 & 0.16 \\
\hline $\begin{array}{c}\text { Asphalt } \\
\text { layers (a) }\end{array}$ & 16 & 5000 & 0.30 \\
\hline $\begin{array}{c}\text { Asphalt } \\
\text { layers (b) }\end{array}$ & 16 & 400 & 0.30 \\
\hline $\begin{array}{c}\text { Unbound } \\
\text { mineral base }\end{array}$ & 20 & 400 & 0.30 \\
\hline $\begin{array}{c}\text { Frost } \\
\text { protection } \\
\text { layer }\end{array}$ & 22 & 200 & 0.30 \\
\hline $\begin{array}{c}\text { Subgrade }- \\
\text { G1 soil }\end{array}$ & $\infty$ & 80 & 0.35 \\
\hline
\end{tabular}

Table 2. Concrete slab parameters used to calculate stress state due to gradient of temperature.

\begin{tabular}{|c|c|c|c|}
\hline Course & $\begin{array}{c}\text { Thickness } \\
\boldsymbol{h}[\mathbf{m m}]\end{array}$ & $\begin{array}{c}\text { Elasticity } \\
\text { module } \\
\boldsymbol{E}[\mathbf{M p a}]\end{array}$ & $\begin{array}{c}\text { Poisson's } \\
\text { ratio } \\
\boldsymbol{v}[-]\end{array}$ \\
\hline $\begin{array}{c}\text { Concrete } \\
\text { slab C35/45 }\end{array}$ & 20 & 26000 & 0.20 \\
\hline
\end{tabular}

The stress state in the structure under the action of static loading was determined by the Finite Element Method using the Abaqus/Standard program. The reinforcement is not considered in the model because its position in the neutral surface of the slab does not affect the values of bending stresses. Therefore, a rotationally symmetric model with CAX8R finite elements was adopted with boundary conditions presented in Fig. 2. The dimensions of the modeled area were assumed large enough to provide that the results of stresses and strains in the structure correspond to those of the half-space. Complete bonding of all layers or free contact between the concrete slab and existing asphalt layers was considered [12].

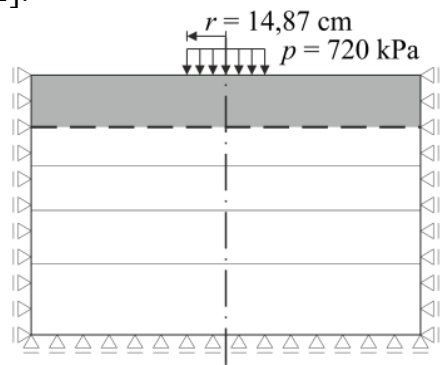

Fig. 2 The computational model of the pavement structure

The maximum value of stress caused by temperature gradient in the concrete slab was calculated from the Westergaard's formula for infinite slab [13]:

$$
\sigma_{t}=\frac{E \alpha_{c} \Delta T}{2(1-v)}
$$

$\Delta T$ - temperature difference between the upper and lower surface of the slab [C],

$\alpha_{c}-$ coefficient of thermal expansion of cement concrete $\left[1 /{ }^{\circ} \mathrm{C}\right]$,

$E$ - modulus of elasticity $[\mathrm{Pa}]$,

$v$ - Poisson's ratio [1].

\subsection{Structural design}

The fatigue life of the pavement was calculated with Miner rule:

$$
\frac{1}{N}=\frac{0.3}{N_{1}}+\frac{0.7}{N_{2}}
$$

$N$ - effective fatigue life of pavement structure [number of standard axles $100 \mathrm{kN}$ ],

$N_{1}$ - fatigue life for sum of wheel loading and thermal loading [number of standard axles $100 \mathrm{kN}$ ],

$N_{2}$ - fatigue life for wheel loading [number of standard axles $100 \mathrm{kN}]$.

Formula for calculating the fatigue durability of concrete slab is presented as follows [13]:

$$
\begin{gathered}
N_{1}=10^{\frac{1}{0.078}\left(1-\frac{n_{1} \gamma_{m}\left(\gamma_{p} \sigma_{p}+\gamma_{t} \sigma_{t}\right)}{f_{f}}\right)} \\
N_{2}=10^{\frac{1}{0.078}\left(1-\frac{n_{1} \gamma_{m} \gamma_{p} \sigma_{p}}{f_{f}}\right)}
\end{gathered}
$$

$f_{f}$ - tensile strength of concrete [Pa],

$\sigma_{p}$ - maximum value of tensile stress in a concrete slab caused by the wheel load $[\mathrm{Pa}]$,

$\sigma_{t}$ - maximum value of tensile stress in a concrete slab caused by the thermal load $[\mathrm{Pa}]$, 
$n_{1}$ - coefficient of load transfer between slabs, $n_{1}=0.9$ for structure with dowels, $n_{1}=0.65$ for structure without dowels, $\gamma_{m}$ - material safety factor, $\gamma_{m}=1.3, \gamma_{p}$ - wheel load safety factor, $\gamma_{p}=1.2, \gamma_{t}-$ thermal load safety factor, $\gamma_{t}=1.2$.

There are three limiting criteria in designing the longitudinal reinforcement in concrete slab [14, 15]:

- crack spacing between $1.2 \mathrm{~m}$ and $2.4 \mathrm{~m}$ for the purpose of reducing the risk of punch-out failure,

- maximum width of crack $1 \mathrm{~mm}$ for reducing the risk of water infiltration and concrete spalling,

- stress in steel not greater than $75 \%$ of yield stress to limit the amount of plastic deformation.

According to AASHTO method [16] the percentage of steel based on crack spacing can be determined by the following equation:

$$
\rho=\frac{1.062\left(1+\frac{f_{t}}{6894000}\right)^{1.457}\left(1+\frac{\alpha_{s}}{2 \alpha_{c}}\right)^{0.25}(1+0.04 \varphi)^{0.476}}{(3.28 \bar{X})^{0.217}\left(1+\frac{\sigma_{p}}{6894000}\right)^{1.13}\left(1+1000 \varepsilon_{c}\right)^{0.389}}-1
$$

For a given crack width the percentage of steel can be calculated from equation:

$$
\rho=\frac{0.358\left(1+\frac{f_{t}}{6894000}\right)^{1.435}(1+0.04 \varphi)^{0.484}}{\left(0.04 w_{\max }\right)^{0.220}\left(1+\frac{\sigma_{p}}{6894000}\right)^{1.079}}-1
$$

While for a given steel stress the percentage of steel can be calculated from equation:

$$
\rho=\frac{50.834\left(1+\frac{\Delta T_{D}}{55.6}\right)^{0.155}\left(1+\frac{f_{t}}{6894000}\right)^{1.493}}{\left(0.000145 \sigma_{s}\right)^{0.365}\left(1+\frac{\sigma_{p}}{6894000}\right)^{1.146}\left(1+1000 \varepsilon_{c}\right)^{0.180}}-1
$$

$f_{t}$ - concrete indirect tensile strength $[\mathrm{Pa}]$,

$\alpha_{c}$ - coefficient of thermal expansion of concrete $\left[1 /{ }^{\circ} \mathrm{C}\right]$,

$\alpha_{s}$ - coefficient of thermal expansion of steel $\left[1 /{ }^{\circ} \mathrm{C}\right]$,

$\varphi$ - reinforcing bar diameter [mm],

$\bar{X}-$ crack spacing $[\mathrm{m}]$,

$\sigma_{p}$ - maximum value of tensile stress in a concrete slab due to wheel load [Pa],

$\varepsilon_{c}$ - concrete shrinkage at 28 days $[\mathrm{m} / \mathrm{m}]$,

$w_{\max }-$ crack width $[\mathrm{mm}]$,

$\Delta T_{D}$ - design temperature drop [ $\left.{ }^{\circ} \mathrm{C}\right]$,

$\sigma_{s}-$ allowable steel stress [Pa]

Geometrical and material data assumed to structural design is presented in Table 3 and Table 4. The material parameters were determined on the basis of own laboratory tests and applicable technical documents.
Table 3. Cement concrete slab parameters

\begin{tabular}{|c|c|}
\hline Parameter & Value \\
\hline $\begin{array}{c}\text { Dimensions of cross-section of the slab: } \\
\text { width }[\mathrm{m}] \times \text { height }[\mathrm{m}]\end{array}$ & $3.0 \times 0.2$ \\
\hline $\begin{array}{c}\text { Concrete tensile strength } f_{f}[\mathrm{MPa}] \\
\text { Concrete indirect tensile strength } f_{t}[\mathrm{MPa}]\end{array}$ & 3.5 \\
\hline $\begin{array}{c}\text { Concrete shrinkage at } 28 \text { days }[\mathrm{m} / \mathrm{m}] \\
\varepsilon_{c}[\mathrm{~m} / \mathrm{m}]\end{array}$ & 0.0002 \\
\hline $\begin{array}{c}\text { Thermal expansion coefficient of concrete } \\
\alpha_{c}\left[1 /{ }^{\circ} \mathrm{C}\right]\end{array}$ & $1.0 \times 10^{-5}$ \\
\hline
\end{tabular}

Table 4. Reinforcement parameters

\begin{tabular}{|c|c|c|}
\hline Parameter & $\begin{array}{c}\text { Value for steel } \\
\text { reinforcement }\end{array}$ & $\begin{array}{c}\text { Value for HFRP } \\
\text { reinforcement }\end{array}$ \\
\hline $\begin{array}{c}\text { Diameter of the bars } \\
\varphi[\mathrm{mm}]\end{array}$ & 20 & 14 \\
\hline $\begin{array}{c}\text { Thermal expansion } \\
\text { coefficient } \alpha_{s}\left[1 /{ }^{\circ} \mathrm{C}\right]\end{array}$ & $1.2 \times 10^{-5}$ & $1.2 \times 10^{-5}$ \\
\hline $\begin{array}{c}\text { Yield stress } f_{y d} \\
{[\mathrm{MPa}]}\end{array}$ & 435 & 870 \\
\hline
\end{tabular}

\section{Calculation results}

The obtained values of the maximum tensile stresses in a concrete slab are presented in Table 5 and the resulting values of fatigue life (according to formulas (2) - (4)) of the pavement structure in Table 6 respectively.

Table 5. Maximum values of tensile stress at the bottom surface of the concrete slab in case of weakened (a) or damaged (b) existing structure

\begin{tabular}{|c|c|c|}
\hline \multirow{2}{*}{ Structure and load variant } & \multicolumn{2}{|c|}{$\begin{array}{c}\text { Degradation of } \\
\text { existing structure }\end{array}$} \\
\cline { 2 - 3 } & $\mathbf{a}$ & $\mathbf{b}$ \\
\hline $\begin{array}{c}\text { Stress due to wheel load in case of full } \\
\text { bonding of concrete slab with existing } \\
\text { structure } \sigma_{p 1}[\mathrm{MPa}]\end{array}$ & 0.75 & 1.32 \\
\hline $\begin{array}{c}\text { Stress due to wheel load in case of } \\
\text { free slip between concrete slab and } \\
\text { existing structure } \sigma_{p 2}[\mathrm{MPa}]\end{array}$ & 1.35 & 1.50 \\
\hline $\begin{array}{c}\text { Stress due to temperature gradient in } \\
\text { case of full bonding of concrete slab } \\
\text { with existing structure } \sigma_{t z}[\mathrm{MPa}]\end{array}$ & 1.3 & 1.3 \\
\hline $\begin{array}{c}\text { Effective tensile stress due to wheel } \\
\text { load } \sigma_{p}=\frac{\sigma_{p 1}+\sigma_{p} 2}{2}[\mathrm{MPa}]\end{array}$ & $\mathbf{1 . 0 5}$ & $\mathbf{1 . 4 1}$ \\
\hline $\begin{array}{c}\text { Effective tensile stress due to thermal } \\
\text { load } \sigma_{t}=\frac{\sigma_{t z}}{2}[\mathrm{MPa}]\end{array}$ & $\mathbf{0 . 6 5}$ & $\mathbf{0 . 6 5}$ \\
\hline
\end{tabular}


Table 6. Computational durability of the pavement structure in case of weakened (a) or damaged (b) existing structure

\begin{tabular}{|c|c|c|}
\hline \multirow{2}{*}{ Durability } & \multicolumn{2}{|c|}{$\begin{array}{c}\text { Degradation of } \\
\text { existing structure }\end{array}$} \\
\cline { 2 - 3 } & $\mathbf{a}$ & $\mathbf{b}$ \\
\hline $\begin{array}{c}\text { Fatigue life for sum of wheel loading } \\
\text { and thermal loading }\end{array}$ & 18 & 1 \\
$N_{1}$ [mln of 100 kN standard axles], & 2422 & 161 \\
\hline $\begin{array}{c}\text { Fatigue life for wheel loading } \\
N_{2} \text { [mln of 100 kN standard axles], }\end{array}$ & $\mathbf{5 9}$ & $\mathbf{4}$ \\
\hline $\begin{array}{c}\text { Effective fatigue life } \\
\text { [mln of 100 kN standard axles], }\end{array}$ & \\
\hline
\end{tabular}

If the existing asphalt pavement of KR3 traffic category is not yet completely cracked (it can be assumed that the modulus of stiffness of existing asphalt layers is around $5000 \mathrm{MPa}$ ), the fatigue life of the structure obtained as a result of using a cement concrete overlay with continuous reinforcement reaches 59 million standard axles, which corresponds to the KR6 traffic category [11]. However, if the existing asphalt layers are completely cracked, we obtain the fatigue durability of the considered structure with an overlay equal to 4 million standard axles, i.e. a construction with the category of traffic KR3.

On the basis of the calculations, it can be concluded that most increasing of strengthened pavement fatigue life is obtained in the case of a structure that has not lost its full load bearing capacity. Generally, it can be concluded that the proper strengthened effect of the pavement is achieved with less slab reinforcement ratio by using HFRP bars compared to steel reinforcement.

The required amount of concrete slab reinforcement determined on the basis of formulas $(5)-(7)$ is given in Tables 7 and 8 .

Table 7. Required amount of reinforcement in case of steel bars in case of weakened (a) or damaged (b) existing structure

\begin{tabular}{|c|c|c|}
\hline \multirow[t]{2}{*}{ Criterion } & \multicolumn{2}{|c|}{$\begin{array}{c}\text { Degradation of } \\
\text { existing structure }\end{array}$} \\
\hline & $\mathbf{a}$ & b \\
\hline $\begin{array}{l}\text { Maximum crack spacing } \bar{X}=2.4 \mathrm{~m} \\
\qquad\left(\rho_{\min }\right)\end{array}$ & $0.46 \%$ & $0.39 \%$ \\
\hline $\begin{array}{l}\text { Minimum crack spacing } \\
\bar{X}=1.1 \mathrm{~m}\left(\rho_{\max }\right)\end{array}$ & $0.73 \%$ & $0.64 \%$ \\
\hline Crack width $w_{\max }=1 \mathrm{~mm}\left(\rho_{\min }\right)$ & $0.49 \%$ & $0.42 \%$ \\
\hline $\begin{array}{l}\text { Allowable stress in reinforcing } \\
\text { bars } \sigma_{s}=0.75 f_{y d}=326 \mathrm{MPa} \\
\left(\rho_{\min }\right)\end{array}$ & $0.62 \%$ & $0.54 \%$ \\
\hline $\begin{array}{l}\text { Required reinforcement } \\
\text { ratio } \rho\left(\rho_{\min } ; \rho_{\max }\right)\end{array}$ & $\begin{array}{l}(0.49 \% \\
0.73 \%)\end{array}$ & $\begin{array}{l}(0.54 \% ; \\
0.64 \%)\end{array}$ \\
\hline
\end{tabular}

The $20 \mathrm{~mm}$ diameter bars were assumed with the 20 $\mathrm{cm}$ spacing, so the percentage of reinforcement was equal to $0.68 \%$
Table 8. Required amount of reinforcement in case of HFRP bars in case of weakened (a) or damaged (b) existing structure

\begin{tabular}{|c|c|c|}
\hline \multirow{2}{*}{ Criterion } & \multicolumn{2}{|c|}{$\begin{array}{c}\text { Degradation of } \\
\text { existing structure }\end{array}$} \\
\cline { 2 - 3 } & $\mathbf{a}$ & $\mathbf{b}$ \\
\hline $\begin{array}{c}\text { Maximum crack spacing } \bar{X}=2.4 \mathrm{~m} \\
\left(\rho_{\text {min }}\right)\end{array}$ & $0.36 \%$ & $0.30 \%$ \\
\hline $\begin{array}{c}\text { Minimum crack spacing } \\
\bar{X}=1.1 \mathrm{~m}\left(\rho_{\max }\right)\end{array}$ & $0.61 \%$ & $0.53 \%$ \\
\hline $\begin{array}{c}\text { Crack width } w_{\text {max }}=1 \mathrm{~mm}\left(\rho_{\min }\right) \\
\text { bars } \sigma_{s}=0.75 f_{y d}=625 \mathrm{MPa} \\
\left(\rho_{\min }\right)\end{array}$ & $0.39 \%$ & $0.33 \%$ \\
\hline $\begin{array}{c}\text { Required reinforcement } \\
\text { ratio } \rho\left(\rho_{\text {min }} ; \rho_{\text {max }}\right)\end{array}$ & $0.26 \%$ & $0.20 \%$ \\
\hline
\end{tabular}

Bars with a diameter of $14 \mathrm{~mm}$ were assumed with a spacing of $18 \mathrm{~cm}$, so the percentage of reinforcement was equal to $0.44 \%$.

In the Table 9 the comparison of key values based on criteria (5) - (7) while considering steel or HFRP reinforcement in case of concrete slab laid on a weakened flexible structure is given.

Table 9. The comparison of key values of the structure with steel or HFRP reinforcement in case of weakened existing layers.

\begin{tabular}{|c|c|c|}
\hline \multirow{2}{*}{ Criterion } & \multicolumn{2}{|c|}{ Reinforcement } \\
\cline { 2 - 3 } & $\begin{array}{c}\text { Steel, } \\
\rho=0.68 \%\end{array}$ & $\begin{array}{c}\text { HFRP, } \\
\rho=0.44 \%\end{array}$ \\
\hline Crack spacing $\bar{X}$ & $1.24 \mathrm{~m}$ & $1.85 \mathrm{~m}$ \\
\hline Crack width $w_{\max }$ & $0.58 \mathrm{~mm}$ & $0.86 \mathrm{~mm}$ \\
\hline Stress in reinforcing bars $\sigma_{s}$ & $297 \mathrm{MPa}$ & $453 \mathrm{MPa}$ \\
\hline
\end{tabular}

On the basis of results of calculations in Tables 7, 8 and 9 , we can conclude that with decreased reinforcement ratio of concrete slabs by using HFRP bars compared with reinforcement by steel bars (decrease by about 35\%), the reinforced pavement reaches comparable fatigue life, though crack width and stress increases in reinforcing bars. By using HFRP bars, this does not effect a decrease durability of the pavement, because these bars are completely resistant to environmental aggression and have very high tensile strength.

\section{Conclusions}

On the basis of these analyses, we can conclude:

1. The use of HFRP new generation bars as continuous reinforcement in concrete slabs to strengthen damaged asphalt pavements is an effective and innovative solution. 
2. Strengthening asphalt pavements using concrete slabs reinforced by HFRP bars increases fatigue life of pavement structure and also increases corrosive resistance of concrete slabs.

3. By using HFRP bars, it is possible to reduce the diameter of bars compared to steel bars and thus to decrease the required amount of reinforcement, without losing the fatigue life of the structure.

4. It was determined that strengthening of the analyzed pavement using slabs with continuous reinforcement is a technology that ensures an increase in the fatigue life by three categories of traffic load, compared with the durability of the pavement before strengthening.

\section{Funding}

This work was supported by the National Centre of Research and Development [grant number NCBR: PBS3/A2/20/2015].

\section{References}

1. J. Piłat, P. Radziszewski, Nawierzchnie asfaltowe. WKi屯, Warszawa (2010)

2. P. Radziszewski, J. Nazarko, T. Vilutiene, K. Dębkowska, J.Ejdys, A.Gudanowska, K. Halicka, J. Kilon, A.Kononiuk, K. Kowalski, J. Król, Ł. Nazarko, M. Sarnowski, Future trends in road pavement technologies development in the context of environmental protection. The Baltic Journal of Road and Bridge Engineering, 11(2), 160-168, (2016)

3. A. Szydło, Pierwszy w Polsce eksperymentalny odcinek nawierzchni betonowej bez szczelin poprzecznych. Zeszyty Naukowe Politechniki Gdańskiej, Nr 603, Budownictwo Lądowe, Nr LX, Gdańsk 2006, 291-298

4. M. Urbański, A. Łapko, Effectiveness of flexural basalt reinforcement application in $R / C$ structures, Monograph Edited by Stanisław Fic: Modern Materials, Installations and Construction Technologies BREST - ODESSA - SIMFEROPOL - BIAŁYSTOK - BIAŁA PODLASKA, 112 -123, Biała Podlaska (2013)

5. A. Garbacz, M. Urbański, A. Łapko, BFRP bars as an alternative reinforcement of concrete structures Compatibility and adhesion issues. Advanced Materials Research (1129), 233-241, (2016)

6. J. R. Roesler, J. E. Hiller, A. S. Brand, Continuously reinforced concrete pavement manual. Guidelines for Design, Construction, Maintenance, and Rehabilitation. U.S. Department of Transportation, FHWA (2016)

7. S. Rizkalla, M. Dawood and M. Shahawy, FRP for Transportation and Civil Engineering Infrastructure: Reality and Vision, Proceedings of the 85th Annual Transportation Research Board (TRB) Meeting, Washington, D.C. (2006)
8. D. Eddie, A. Shalaby and S. Rizkalla, Glass FiberReinforced Polymer Dowels For Concrete Pavements. ACI Structural Journal, 98, 201-206, (2001)

9. Fareed Elgabbas, Ehab A. Ahmed, Brahim Benmokrane: Physical and mechanical characteristics of new basalt - FRP bars for reinforcing concrete structures. Construction and Building Materials. 95, 623-635, (2015)

10. Katalog Typowych Konstrukcji Nawierzchni Podatnych i Półsztywnych (2014)

11. Katalog Typowych Konstrukcji Nawierzchni Sztywnych (2014)

12. ABAQUS Analysis User's Manual, Ver. 6.8, Hibbit, Karlsson \& Sorensen Inc., USA (2008)

13. A. Szydło, Nawierzchnie drogowe $z$ betonu cementowego, Polski Cement, Kraków (2004)

14. N. Delatte, Concrete Pavement Design Construction and Performance, New York, London (2008)

15. R. B. Mallick, T. El-Korchi, Pavement Engineering. Principles and Practice, New York (2018)

16. AASHTO Guide for Design of Pavement Structures (AASHTO 86/93). American Association of State Highway and Transportation Officials, (1993) 